\title{
G.
}

ISSN 2278 - 0211 (Online)

\section{Social Studies Methods: Constancy and Change}

\author{
Dr. Gimba, Joseph \\ Chief Lecturer, Department of General Studies, Taraba State College of Agriculture, Nigeria \\ Gimba, Matthew \\ Lecturer, Department of Political Science, Taraba State College of Education, Nigeria \\ Soguna, Macdonald Daniel \\ Lecturer, Department of General Studies, Federal Polytechnic Bali, Taraba State, Nigeria
}

\begin{abstract}
:
Social studies are the integrated study of the social sciences and humanities to promote civic competence. Within the school curriculum, social studies provide coordinated, systematic study drawing upon disciplines as anthropology, archaeology, economics, geography, history, law, philosophy, political science, psychology, religion, and sociology, as well as appropriate content from mathematics, and natural sciences. Social studies are that part of the school's general education programme which is concerned with the preparation of citizens for active participation in a democratic society. The aim of social studies education is to help students acquire a wide range of tested social theory, and principles relevant to contemporary social issues and beliefs. The primary purpose of social studies is to help young citizens develop the right values and ability to make informed and reasoned decisions for the public good as citizens of an ethnically and culturally diverse, democratic society through critical thinking in a globally interdependent world. It is in line with this goal that different methods to transmit knowledge have been developed. Just like many other academic disciplines, social studies as a school subject adopts many methods to transmit knowledge to the learner. Some of these methods are either teacher-centered, student-centered or Teacher-student interactive centered. As a discipline aimed at developing the civic competence of citizens, to support democracy and developed requisite skills for critical thinking and problem solving a systematic way isvery imperative for the teaching and learning of social studies at the levels it is taught in Nigeria. The size of the class and lesson objectives are some of the variables that determines method the teacher will use. Part of the recommendation made in this paper is that a more robust approach in the teaching of social studies is paramount rather than the traditional methods which have dominated the field since its introduction as a school subject in Nigeria.
\end{abstract}

Keywords: Social studies, constancy, change, method, self-directed learning

\section{Introduction}

According to Edinyang, Unimke, Ubi, Opoh and Iwok (2015), Social Studies is seen as a discipline that helps students become responsible citizens in a culturally diverse, democratic society within an interdependent world. Social Studies was introduced into school curricula following the 1968 Mombassa conference where African Social Studies Programme (ASSP) was launched as a continental strategy for citizenship training, the emergent quest for nation building and national development (Ahmad 2013). The introduction of Social Studies in Nigeria was mainly to inculcate concept of patriotism, nationalism, discipline, tolerance, respect to constituted authority, hard work, understanding, unity in diversity and interdependence among the citizens of the new nation. These cannot be achieving without proper methods and strategies to impact positively on the life of the students. These methods so selected to engage the students in solving problems themselves and to help them discover their potentials in critical thinking and other necessary skills and knowledge that will endear them to nation building. Though these methods are many and devise, they are important in fostering and inculcating the desired concepts, ideas, knowledge skills, norms, mores and values that can make them independent and helpful to the societies. Right from its introduction into the curriculum of Nigerian schools, the potentials of the Social Studies programme in promoting values, ethics of inter-ethnic understanding has never been in doubt (Garba, 2013).

Methods like, Group methods, Play-way methods, Inquiry methods, Presentation methods, Dramatization method, Discussion method, Creative activity method and many others have paved a way for the actualization of Social Studies objectives.

\section{Methods in Social Studies}

Social Studies method is "an orderly arrangement of activities and systematic procedure of doing things. It sets guidelines for the patterns of behavior the teacher expects from the learners in class (NOUN, 2007:56). Method is therefore a teacher's approach to instruction on facts, concepts and generalizations, that is a systematic way in which teachers approach their teaching. Social Studies methodology is based on the fundamental principles recommended for its 
teaching and learning. These principles include integration, guided problem-solving interdisciplinary or multidisciplinary and use of learners' environment. Whereas various methods, approaches, techniques and strategies are encouraged in the teaching and learning of Social Studies, specifically, child-centered methods are highly encouraged and recommended. This means that learners should be actively engaged in their own learning under the teacher's guidance (NOUN, 2007:56). Ideally, to ensure that Social Studies is taught very well, it is pertinent that methods of teaching it is explained. Often those who write about the Social Studies curriculum and teaching Social Studies confuse methods and techniques or use them interchangeably as synonyms (Sofadekan, 2012). While teaching methods in Social Studies have been the focus of professional discourse among Social Studies educators, most especially since the introduction of the subject into the Nigeria school curriculum (Sofadekan, 2012), the value of instructional strategies in facilitating and motivating learning has never been in dispute (Akinlaye, 2002). While it is perceived that some teaching methods can effectively promote the learning of key concepts, facts, generalizations, and skills in Social Studies better than others, there is no consensus as to which of them can facilitate effectively and efficiently critical and reflective thinking that may lead directly to intelligent and rational decision-making on social issues and problems of the environment. It is the professional obligation of the teacher to employ effective and conducive approaches of stimulating, motivating and managing learning development in a classroom setting (Sofadekan, 2012). Some of the common methods in social studies are:

\subsection{Presentation Method Presentation Methods: Uses The Technique of:}

\subsubsection{Lecture}

- Story telling

- Illustrated talk

- Demonstration

- Visiting speaker

2.2. Creative Activity Method: Uses The Techniques of:

\subsubsection{Drawing and panting}

- Poster

- Creative writing

- Cartoons

- Costume making

- 0258ConceptMapping

2.3. Discussion Method: Uses The Technique of:

- Brainstorming

- Small group discussion

- Large group discussion

- Debate

- v. Panel discussion

- vi. Devil's advocate

2.4. Dramatization Method: Use The Technique of:

- Miming

- Playlet

- Role playing

- Monologues / Dialogues

- Puppetry

2.5. Inquiry-Problem Solving Method: Use The Technique of:

- Field trips

- Quizzes

- Puzzles

- Sorting

- Opinion polls (NTI/ DLS, Book. 7.2004; Sofadekan, 2012 ;).

It can be seen from the discussion above that teaching methods are tools used to accomplish specific instructional objectives. These methods have been identified to be the commonest employ by teachers.

\section{Changing Trend in Social Studies Method}

The Social Studies subject encompass diverse concerns of society and include a wide a range of content, drawn from the disciplines of history, geography, political science, economics and sociology. Therefore, Social Studies teaching needs to be revitalized towards helping the learner acquire knowledge and skills in an interactive environment. In order to make the process of learning participative there is a need to shift from mere imparting of information to debate, discussion and action. This approach to learning will keep both the learner and teacher alive to social realities. 
There are many useful teaching methods to support effective teaching in Social Studies to keep students motivated and fully occupied, but there is no single method of teaching which fits all the learning situations. Therefore, to make the learning of Social Studies more enjoyable and effective, there is a need for innovations in teaching methods. These changes are very necessary to match with the dynamics of our environments.

In recent times there has been research and scholarly work on methods of teaching Social Studies, even though these methods vary from country to country. For our purpose, we will examine self-directed learning as a new trend in methods of teaching social studies.

\section{Concept of Self-Directed Learning}

Self-directed learning, which has its roots in adult education, is an approach that has also been tried with learners in elementary and secondary schools. There may be slight variations in how different educators define Self-Directed Learning, but a survey of the literature on the subject identifies several tenets that are central to the concept. As the term suggests, Self-Directed Learning views learners as responsible owners and managers of their own learning process. SelfDirected Learning integrates self-management (management of the context, including the social setting, resources, and actions) with self-monitoring (the process whereby the learners monitor, evaluate and regulate their cognitive learning strategies) (Bolhuis, 1996; Garrison, 1997). Self-Directed Learning recognizes the significant role of motivation and volition in initiating and maintaining learners' efforts. Motivation drives the decision to participate, and volition sustains the will to see a task through to the end so that goals are achieved (Corno, 1992; Garrison, 1997). In Self-Directed Learning, control gradually shifts from teachers to learners. Learners exercise a great deal of independence in setting learning goals and deciding what is worthwhile learning as well as how to approach the learning task within a given framework Self-Directed Learning is, ironically, highly collaborative. Learners collaborate with teachers and peers in (Guthrie, Solomon\& Rinehart; 1997; Temple \& Rodero, 1995). Self-Directed Learning develops domain-specific knowledge as well as the ability to transfer conceptual knowledge to new situations. It seeks to bridge the gap between school knowledge and real-world problems by considering how people learn in real life (Bolhuis, 1996; Temple \&Rodero, 1995). Several perspectives from the literature on Self-Directed Learning have emerged over the years. However, the concept is usually viewed more broadly as a process of learning in which people take the primary responsibility or initiative in the learning process, and a personal attribute of the learner (Manning, 2007).

\section{The Role of Teachers in Self-Directed Learning}

Learner participation in decision-making is another fundamental aspect of the SDL approach. Taylor advocates involving students in decisions concerning what is to be learned, when and how it should be learned, and how it should be evaluated. Teachers could, for instance, establish a thematic framework within which students are given choices (Guthrie, Solomon \& Rinchart, 1997; Temple \& Rodero, 1995). Lyman (1997) and Bolhuis (1996) stress that teachers who want to encourage Self-Directed Learning must free themselves from a preoccupation with tracking and correcting errors, a practice Guthrie, Solomon \& Rinchart, (1996) describe as ego-threatening.

\section{Activity Based Learning}

This method is based on doing some hands-on experiments and activities. The students become active learners rather than passive recipients of information. The children are provided the opportunity to explore by their own so that the learning becomes joyful and long-lasting.

\section{Computer Aided Learning (Cal)}

In this method specially designed software applications are used to learn a subject. This creates an environment, where learning and assessment is fun and the opportunities to learn is equitable among the rural and urban children. The main objective of this programme is to attract the children, retain them in the schools and to improve the quality of the education through animated multimedia based educational content.

\section{Constancy and Change}

The changes so required are to be view from many perspectives, though the learners (pupils or students) we know will remain Constance, methods and circumstance changes to accommodate contemporary challenges.Though change is constant in organizations, determining how to successfully implement planned change has been a perennial challenge for both organizational scholars and practitioners. While the empirical knowledge base on planned change in schools and other organizations offers numerous insights, the inattention to activity, or the practice of leading and managing change, remains. Organizational change theory, and specifically organizational routines, offers a useful lens with which to examine planned change in work practice in schools.

New routines can serve as a mechanism to build instructional coherence, internal accountability, and professional community. This account suggests that one way to change norms and culture in an organization is through the design and implementation of new routines. Leaders can create opportunities for change in school practice. By designing and supporting an organizational routine, the teachers in Social studies focused the practice of the faculty on improving teaching and learning in ways they think best for the students under the circumstances. The teachers demonstrate that in the enactment of a routine, school staff can also create change in practice. How they make sense of the routine, and integrate it into their practice, can create shifts in teaching and learning. Change happens in the interplay between individual agency and the structure of the routine. The teachers' methods of teaching can enable both change and constancy in school practice (Coburn, 2008). 


\section{Conclusion}

Social Studies methodology is based on the fundamental principles recommended for its teaching and learning. These principles include integration, guided problem-solving interdisciplinary or multidisciplinary and use of learners' environment. Whereas various methods, approaches, techniques and strategies are encouraged in the teaching and learning of Social Studies, specifically, child-centered methods are highly encouraged and recommended. This means that learners should be actively engaged in their own learning under the teacher's guidance.

\section{Recommendations}

In view of the prevailing challenges and problems of integration in Nigeria. The following is therefore recommended.

a. social studies teachers should adopt robust teaching methods that will develop citizens

problem solving and critical thinking skills.

- Teacher re-training programme should be carried out to update the skills of social studies teachers.

- Social studies teacher should explore other methods of teaching social studies for effective knowledge construction

- Social studies teachers should use student-centered methods more often than traditional methods which has dominated the teaching profession

\section{References}

i. Ahmad, A. (2013). Role of social studies education in national development in Nigeria. Academic Journal of Interdisciplinary Studies (MCSER-CEMAS-Sapienza University of

ii. Rome) 2 (6).

iii. Atang R. S. (2013). Citizenship education: A prerequisite for National Integration in Nigeria. Akamkpa Journal of Education. 2. (2).

iv. Awhen,O.F., Edinyang, S. D, \&lpuole, O.D. (2014) Introduction of social studies Education in Nigeriaschools: A success or Failure. International Journal of Educational and Research.Vol.2 (4).

v. Coburn, C. E., \& Russell, J. L. (2008). District policy and teachers' social networks. Educational Evaluation and Policy Analysis, 30(3), 203-235 from:https:/ / www.researchgate.net/ publication/ 290793832 Constancy_and_Change_in_Work_Practice_in_School s The Role of Organizational Routines [accessed May 17 2019].

vi. Dan, $\bar{B}$. (2010) Application of the integrated approach in Teaching social studies in Ibanda PTC and selected Primary schools in IbandaDistrict. Unpublished thesis of Makerere University

vii. Edinyang, S. D., Unimke, S. A., Ubi, I. E., Opoh, F. A., Iwok, A. A. (2015). Historical Foundation of Social Studies Education. Calabar: Word of life publishers.

viii. Edinyang, S.D., Mezieobi, D.I., Ubi, I.E (2013). Selected Issues in Social Studies Education:

ix. Calabar: Maesot\& Company.

x. Egomo, J. E. (2011) Social Studies for Tertiary Institutions. Calabar: SIIT Computers.

xi. Fan, A.F (2014). Issues in Social Studies and Civic Education in Nigeria Schools. Hi-Tech

xii. Tower industries services Ltd., Abuja: Garki.

xiii. Federal Ministry of Education (2008) (4th Edition) National Policy of education Lagos:

xiv. NERDC press.

xv. Federal Republic of Nigeria (2008). National Policy on Education: Lagos: Nigeria Educational Research and Development Council (NERDC).

xvi. Garba, M. A. (2013). Social studies education: A tool for promoting intercultural education. Journal of Academic Excellence. MCSER-CEMAS: Sepienzza University of Rome. 2(8).

xvii. Mofarland, M.A (2004). Social studies: what is it, why do we need it? In National Council for Social Studies (Ed) social studies services: Washington, D.C: Author Press.

xviii. Nnoli, O. (1999). Ethnic Politics in Nigeria: Enugu: Fourth Dimension Publishers.

xix. Nwanna-Nzewunwa, O.P (2006). Repositioning social studies education in Nigeria seniorsecondary school: The missing link, Multidisciplinary Journal of Research Development,7 (2).

xx. Oyibe, O. A. \& Nnamani, S. C. (2016) Achieving Nigeria Educational Objectives through Effective Social Studies Instruction IOSR Journal of Research \& Methods in Education 6(4). 